UN PEACEKEEPING IN AFRICA AND GOOD GOVERNANCE: CHALLENGES AND PROSPECTS

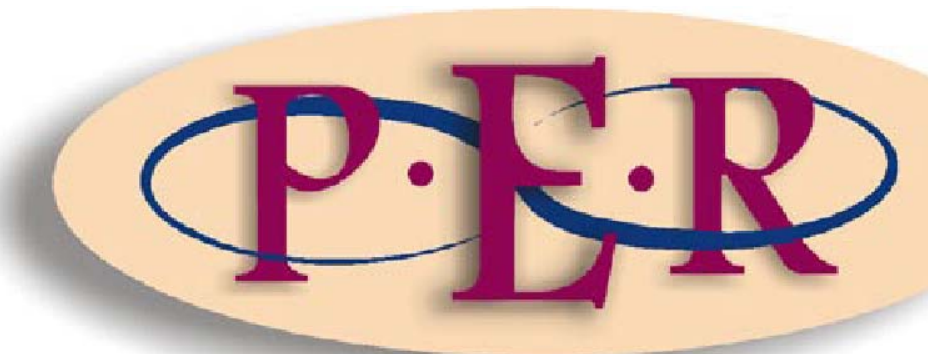

2008 VOLUME 11 No 2 


\section{UN PEACEKEEPING IN AFRICA AND GOOD GOVERNANCE: CHALLENGES AND PROSPECTS}

\section{W van Genugten *}

\section{Introduction and set-up of the paper}

'UN peacekeeping' and 'Africa' are not a natural fit. The combination of words is associated more often with failures than with success stories. While UN peacekeeping operations are in most cases anyhow confronted with a multitude of intertwined problems, this seems to be even worse in Africa. African operations have to react more than averagely to inter- as well as intrastate conflicts based upon ethnic tension, to conflicts starting from extreme poverty or the abuse of natural resources, and to situations in which governments are failing to do what governments should do. In the present paper the mandates of the six ongoing UN peacekeeping operations on African soil are analysed from the perspective of their (desired) contribution to the establishment of good governance structures.

The paper starts by giving some general background on peacekeeping in Africa and on the concept of good governance (section 2), followed by a detailed investigation of good governance at six ongoing African peacekeeping operations (section 3). Having done so, the paper continues by presenting more general observations as to trends in UN peacekeeping and their consequences for Africa (section 4), followed by a summary and some overall concluding observations (section 5).

The research has been concluded at 1 May 2007.

* Prof Willem van Genugten, Professor of International Law, Tilburg University, The Netherlands. 


\section{The core concepts of the paper}

\subsection{Peacekeeping in Africa}

Since its first official peacekeeping operation - the United Nations Emergency Force (UNEF 1), active in the Middle East from 1956 to 1967 - the UN have deployed about sixty such operations. They have been started and maintained for a variety of reasons which however are often not evidently covered by the word 'peacekeeping'. Sometimes there is no peace to be kept at all, and is the mandate of the missions more related to peace-enforcement - in which cases the UN these days often cooperates with NATO - or to, for instance, reconstruction of governmental and other structures. In the latter case, the label 'peace-building' is commonly used. Nevertheless, the word 'peacekeeping' is still standard - including within the UN itself - as an overall phrase for this variety of operations.

Using different labels, one should keep in mind that this is about more than words only. The so-called 'Brahimi report', evaluating the UN peacekeeping system after some failures in the early 1990s and to be discussed from the perspective of the present paper later on, states that it should have come as no surprise

...that some of the missions of the past decade would be particularly hard to accomplish: they tended to deploy where conflict had not resulted in victory for any side, where a military stalemate or international pressure or both had brought fighting to a halt but at least some of the parties to the conflict were not seriously committed to ending the confrontation. United Nations operations thus did not deploy into post-conflict situations but tried to create them. In such complex operations, peacekeepers work to maintain a secure local environment while peace-builders work to make that environment self-sustaining. Only such an environment offers a ready exit to peacekeeping forces, making peacekeepers and peace-builders inseparable partners. ${ }^{1}$

1 Report of the Panel on United Nations Peace Operations, chaired by Lakhdar Brahimi. UN Doc A/55/305, 21 August 2000 at viii. 
This language reflects the dynamics in (thinking about) peacekeeping operations and shows some of the problems this paper will discuss in sections two and three.

In this section the observation is maintained that 16 out of the 44 operations of the past related to African States, while six out of the current 15 operations situation as of 1 May 2007 - are deployed in Africa. ${ }^{2}$ A relatively substantial number, even if we keep in mind that Africa is a large continent, as of now encompassing 53 states at a total of 192 UN Member States. African operations in the past took place in thirteen states: Angola, Burundi, Central African Republic, Chad, Congo, Libya, Liberia, Mozambique, Namibia, Rwanda, Sierra Leone, Somalia, and Uganda. As of now operations are going on in Côte d'Ivoire, the Democratic Republic of the Congo, Ethiopia and Eritrea, Liberia, Sudan, and the Western Sahara. ${ }^{3}$

\subsection{Good governance}

Over the last couple of decades, a wealth of academic and policy-oriented literature on good governance has been produced, clarifying and criticising the concept as well as making it as operative as possible. The latter relates to the use of the concept in the areas of especially international development and international economic relations, for example, through practices developed by the World Bank and the International Monetary Fund (IMF). ${ }^{4}$ Further to that, the concept is elaborated upon in, for instance, the context of discussions on the UN human rights machinery. ${ }^{5}$ The present paper does not intend to discuss the concept of good governance in itself, but focuses upon its links to the field of peace and security. As a matter of fact, it would be easy to elaborate in a lengthy way upon the concept of good governance, but for the present paper it would do to follow the no-nonsense approach as taken by, amongst others, the United Nations Economic and Social Commission for Asia and the Pacific

UN http://www.un.org/Depts/dpko/dpko/ 17 Jul.

Ibid.

See, most recently, Hout Politics of Aid Selectivity.

See, out of many sources, Alfredson, Clapp and Sano (eds) Human Rights and Good Governance, and Sepulveda et al (eds) Human Rights Reference Handbook 407-409. 
(UNESCAP). According to UNESCAP, 'governance' means, simply put, "the process of decision-making and the process by which decisions are implemented (or not implemented)", while the word governance is used "in several contexts such as corporate governance, international governance, national governance and local governance". ${ }^{6}$

In the context of the present paper the focus will be on the establishment of effective national governments, on the (human rights and other) values they have to take into account when performing their governmental tasks, and on the role UN peacekeepers can play in the process of paving the way towards a situation in which national governments can effectively "handle their own business". In the words of UNESCAP, further dividing the issue in manageable parts, one would have to take into account eight major factors/characteristics when discussing and practising good governance:

It is participatory, consensus oriented, accountable, transparent, responsive, effective and efficient, equitable and inclusive, and follows the rule of law. ${ }^{7}$

Further to that, or better: as part of that, it also "assures that corruption is minimized", that "the views of minorities are taken into account", that "the voices of the most vulnerable in society are heard in decision-making" and that it is also "responsive to the present and future needs of society". 8

Before proceeding, a few explanatory words might be needed on the subconcepts used by UNESCAP that are relevant for the present paper as well. In the order in which the core characteristics have been presented before:

- Participation by both men and women could be either direct or through legitimate intermediate institutions or representatives. Representative democracy does not necessarily mean that the concerns of the most vulnerable in society would be taken into consideration in decision-

6 UN http://www.unescap.org/pdd/prs/ProjectActivities/Ongoing/gg/governance.asp 17 Jul.

7 Ibid.

8 Ibid. 
making. Participation needs to be informed and organised. This means freedom of association and expression on the one hand and an organised civil society on the other hand.

- Consensus oriented. Good governance requires mediation of the different interests in society to reach a broad consensus on what is in the best interest of the whole community and how this can be achieved. It also requires a broad and long-term perspective on what is needed for sustainable human development and how to achieve the goals of such development.

- Accountability is a key requirement of good governance. Not only governmental institutions but also the private sector and civil society organisations must be accountable to the public and to their institutional stakeholders. Who is accountable to whom varies depending on whether decisions or actions taken are internal or external to an organisation or institution. In general an organisation or an institution is accountable to those who will be affected by its decisions or actions. Accountability cannot be enforced without transparency and the rule of law.

- Transparency means that decisions taken and their enforcement are done in a manner that follows rules and regulations. It also means that information is freely available and directly accessible to those who will be affected by such decisions and their enforcement. It also means that enough information is provided and that it is provided in easily understandable forms and media.

- Responsiveness. Good governance requires that institutions and processes try to serve all stakeholders within a reasonable timeframe.

- Effectiveness and efficiency. Good governance means that processes and institutions produce results that meet the needs of society while making the best use of resources at their disposal. The concept of efficiency in the context of good governance also covers the sustainable use of natural resources and - in the long run - the protection of the environment. 
- Equity and inclusiveness. A society's well being depends on ensuring that all its members feel that they have a stake in it and do not feel excluded from the mainstream of society. This requires all groups, but particularly the most vulnerable, have opportunities to improve or maintain their well being.

- Rule of law. Good governance requires fair legal frameworks that are enforced impartially. It also requires full protection of human rights, particularly those of minorities. Impartial enforcement of laws requires an independent judiciary and an impartial and incorruptible police force. ${ }^{9}$

I would like to add two issues, relevant for the remainder of this paper. The first issue relates to the notion that time and again one has to transcend the idea that 'governance' is still basically about (traditional) governments who are in the lead of 'their' sovereign states. Governments are no doubt extremely important and central to the concept of good governance, but the major tasks they have to fulfil cannot be separated from non-state actors, such as populations, minorities included, companies and non-governmental organisations, the latter including for instance the media (although these are often also to be considered as state actors). Some of these non-state actors are already mentioned in the point-wise presented overview of core characteristics of good governance borrowed from UNESCAP, while it could be added here - having an eye upon Africa - mixes of state and non-state actors, such as influential land lords, associations of farmers, and cooperatives, and state-based international actors such as the International Financial Institutions (mainly the World Bank and the IMF) and, in the context of the present paper, UN peacekeeping forces.

The second issue concerns reading the eight key characteristics of good governance with 'human rights eyes'. The word 'participation' does include some core human rights (for instance: the freedom of association and the freedom of expression), while UNESCAP's words 'consensus oriented' do touch upon the notion of the so-called third generation of human rights, by

9 The descriptions of the eight sub-concepts are based upon UNESCAP's wordings, and slightly modified and adapted to the scope of the present paper. 
referring to the long-term perspective "on what is needed for sustainable human development". Further to that, the description of 'effectiveness and efficiency' includes notions such as "sustainable use of natural resources and the protection of the environment", being notions that are more and more linked to the concept of human rights. In addition, the phrase 'rule of law' is rightly said to refer to the "full protection of human rights", although it might mean much more than the UNESCAP author(s) of that line had in mind when writing it down. That is to say: the United Nations have adopted about hundred human rights instruments, ${ }^{10}$ covering a huge diversity of rights. Some of these rights would be more important than others, in general as well as from the perspective of good governance. The Code of Conduct for Law Enforcement Officials, for instance, would be more relevant in that respect than the Convention on Consent to Marriage, Minimum Age for Marriage and Registration of Marriages. Some might even see the latter as a good governance issue, but in that case good governance would embrace everything, while the concept is already (too) broad.

\section{Peacekeeping operations in Africa and good governance}

\subsection{Introduction}

Twenty-two UN peacekeeping operations of the past and the present related or still relate to Africa. It would be beyond the scope of this paper to discuss all of them, be it only from a good governance perspective, while, on the other hand, it would also be risky to draw general conclusions as to UN peacekeeping operations in Africa without carefully discussing each of them on an individual basis. In terms of methodology, I therefore made the choice to discuss the (six) operations going on as of 1 May 2007, thereby focusing upon their mandates, official resolutions and statements as to their aims, and reading these with the good governance glasses as grinded in the introductory chapter of this paper. 


\subsection{Six ongoing African operations}

The six UN operations will be discussed in chronological order, thereby first for a correct understanding shortly describing to what problem they want to be the solution, ${ }^{11}$ followed by a short presentation of the relevant parts of their mandates.

\subsubsection{Western Sahara (MINURSO, 1991- )}

Being administered by Spain until 1976, the Western Sahara is since then leaving aside the earliest years after 1976 when neighbouring country Mauritania also wanted to incorporate the territory - claimed by Morocco as well as the Frente Popular para la Liberación de Saguia el-Hamra y de Río de Oro (Frente POLISARIO). Following the acceptance of 'settlement proposals' by the two parties in 1988, the UN Security Council decided in 1991 to establish the Mission for the Referendum in Western Sahara (MINURSO). ${ }^{12}$ Since 1991 , the Security Council adopted another 34 resolutions, in most cases related to the extension of the mandate - as of now until 31 October $2007^{13}$ - and the adaptation of the mandate to new challenges. ${ }^{14}$

MINURSO is mandated to monitor the ceasefire, verify the reduction of Moroccan troops from the Western Sahara, et cetera, but also:

- $\quad$ to implement the repatriation programme (...);

- to identify and register qualified voters;

- to organise and ensure a free and fair referendum and proclaim the results. $^{15}$

11 The UN Department of Peacekeeping Operations is maintaining a website for each country. These websites have served as the main source of information for the descriptions of the country situations, other sources having been consulted where relevant for a correct understanding. It should be added that the UN websites are much more detailed than the descriptions presented here. The latter can be seen as short summaries of often long histories, minimally needed in order to understand the reasoning behind the six operations. In later sections, references will be made to the relevant websites. SC Resolution 690, 29 April 1991.

13 SC Resolution 1754, 30 April 2007.

14 See for an overview: UN http://www.un.org/Depts/dpko/missions/minurso/res.html 17 Jul.

15 UN http://www.un.org/Depts/dpko/missions/minurso/mandate.html 17 Jul. 


\subsubsection{Liberia (UNOMIL/UNOL/UNMIL, 1993 -)}

Liberia, being an independent republic since 1847, was confronted at the end of the 1980s with a devastating civil war. The Economic Community of West African States (ECOWAS), undertook various initiatives aimed at a peaceful settlement. These initiatives included an ECOWAS's observer force, supported by a UN Security Council resolution imposing an arms embargo on Liberia. ${ }^{16}$ After ECOWAS brokered a peace agreement, the Security Council in 1993 established the United Nations Observer Mission in Liberia (UNOMIL). UNOMIL ended in 1997. Its tasks included to exercise good offices in support of the efforts of the ECOWAS and the Liberian National Transitional Government to implement the peace agreements, to investigate human rights violations and assist local human rights groups, and to observe and verify elections. ${ }^{17}$

In November 1997, following the completion of UNOMIL's mandate, the UN established the United Nations Peace-building Support Office in Liberia (UNOL). This operation had a mandate to, inter alia, assist the government in consolidating peace following the July 1997 multiparty elections. ${ }^{18}$ However, as the UN stated, the peace-building efforts of UNOL "were seriously hindered by the inability of the Government and opposition party leaders to resolve their differences over key issues of governance", while the systematic abuses of human rights, the exclusion and harassment of political opponents and the absence of security sector reform contributed to the resumption of civil war in Liberia, "prompting the international community to call on the warring parties to seek a negotiated settlement of the conflict". ${ }^{19}$ As a reaction, in September 2003, the Security Council decided to establish the present United Nations Mission in Liberia (UNMIL). ${ }^{20}$ Its mandate - extended several times, as of now until September $2007^{21}$ - includes, apart from the core task to observe and

$1617 \mathrm{Jul}$ http://www.un.org/Depts/dpko/missions/unmil/background.html 17 Jul.

17 SC Resolutions 866, 22 September 1993 and 1020, 10 November 1995. Also see UN http://www.un.org/Depts/dpko/dpko/co mission/unomil.htm 17 Jul.

18 UN http://www.un.org/Depts/dpko/missions/unmil/background.html 17 Jul.

19 UN http://www.un.org/Depts/dpko/missions/unmil/background.html 17 Jul.

20 SC Resolution 1509, 19 September 2003.

21 SC Resolution 1750, 30 March 2007, at par 1.

$50 / 252$ 
monitor the implementation of the ceasefire agreement and to investigate violations of the ceasefire and related peace and security obstructions, the following tasks:

- to facilitate the provision of humanitarian assistance (...);

- to contribute towards international efforts to protect and promote human rights in Liberia, with particular attention to vulnerable groups including refugees, returning refugees and internally displaced persons, women, children, and demobilised child soldiers (...);

- to assist the transitional government of Liberia in monitoring and restructuring the police force of Liberia, consistent with democratic policing, to develop a civilian police training programme, and to otherwise assist in the training of civilian police (...);

- to assist the transitional government in the formation of a new and restructured Liberian military (...);

- to assist the transitional Government (...) in re-establishment of national authority throughout the country, including the establishment of a functioning administrative structure at both the national and local levels;

- to assist the transitional government (...) in developing a strategy to consolidate governmental institutions, including a national legal framework and judicial and correctional institutions;

- to assist the transitional government in restoring proper administration of natural resources;

- to assist the transitional government (...) in preparing for national elections $(\ldots)^{22}$

\subsubsection{Democratic Republic of the Congo (MONUC, 1999-)}

Having become an independent state in 1960, the Democratic Republic of the Congo (DRC), has gone through major conflicts and difficult transitional periods, already leading to a UN Peacekeeping Operation in the 1960 s. $^{23}$ That 
force, which will be further neglected here, is said to have left the country "united, but politically unsettled and facing continued secessionist threats in key regions". ${ }^{24}$ Following Mobutu's coup of 1965, the country neutralised the political opposition and thwarted secessionist tendencies with methods, including the arrest and humiliation of former allies and the elimination of independent labour unions that were "authoritarian but not unusual among Third World countries at that time". ${ }^{25}$ Political and economic initiatives taken by Mobutu in the 1970s were confronted with serious resistance and finally contributed to the civil wars of 1996-1997 and 1998-1999. ${ }^{26}$

The latter civil war was 'concluded' by the Lusaka ceasefire agreement, signed by the warring parties in July-August 1999. After some interim proposals and measures, not very relevant for the present paper, the UN Security Council decided in November 1999 that the personnel authorised under its previous resolutions on the situation in the DRC, including

a multidisciplinary staff of personnel in the fields of human rights, humanitarian affairs, public information, medical support, child protection, political affairs and administrative support ... shall constitute the United Nations Organization Mission in the Democratic Republic of the Congo (MONUC). ${ }^{27}$

A few months later, the Security Council formulated MONUC's mandate. ${ }^{28}$ It included, apart from a series of military aspects related to the ceasefire agreement, issues such as:

- to facilitate humanitarian assistance and human rights monitoring, with particular attention to vulnerable groups including women, children and demobilised child soldiers (...). 
In 2004, MONUC's mandate was revised and updated. ${ }^{29}$ Since then the mandate - as of now extended until 15 May $2007^{30}$ - includes:

- to contribute to arrangements taken for the security of the institutions and the protection of officials of the Transition in Kinshasa until the integrated police unit for Kinshasa is ready to take on this responsibility and assist the Congolese authorities in the maintenance of order in other strategic areas (...);

- to contribute to the improvement of the security conditions in which humanitarian assistance is provided, and assist in the voluntary return of refugees and internally displaced persons;

- to contribute to the successful completion of the electoral process (...), by assisting in the establishment of a secure environment for free, transparent and peaceful elections to take place.

It was further decided, by the same Resolution, that MONUC will also have the mandate to provide advice and assistance to the transitional government and authorities, as to:

- essential legislation, including the future constitution;

- security sector reform, including the integration of national defence and internal security forces together with disarmament, demobilisation and reintegration, and, in particular, the training and monitoring of the police, while ensuring that they are democratic and fully respect human rights and fundamental freedoms;

- the electoral process.

\subsubsection{Ethiopia and Eritrea (UNMEE, 2000 - )}

Fighting between Eritrea and Ethiopia erupted in May 1998, as a result of a border dispute. Successively, the Organisation of African Unity (OAU) organised a summit in Algiers in July 1999, at which the two parties accepted a 
peace document. Despite the agreement, the fighting between the two states erupted again in May 2000, leading to renewed peace talks in Algiers and another peace agreement, signed in June $2000 .{ }^{31}$

The new agreement called upon the UN, in cooperation with the OAU, to establish a peacekeeping operation. On 31 July 2000 the UN Security Council decided to establish the United Nations Mission in Ethiopia and Eritrea (UNMEE). ${ }^{32}$ The core of the mandate - as of now extended until 31 July $2007^{33}$ - relates to the cessation of the hostilities. ${ }^{34}$ In a resolution of September 2000, UNMEE's mandate was expanded with, among other things, the task to

coordinate the Mission's activities in the temporary security zone and areas adjacent to it with humanitarian and human rights activities of the United Nations and other organizations in those areas. ${ }^{35}$

\subsubsection{Côte d'Ivoire (MINUCI/UNOCI, 2003-)}

Côte d'Ivoire, having become an independent state in 1960, had a relatively good start in terms of political stability and socio-economic prosperity. Following the death of its founding leader in 1993, however, it was confronted with a power struggle, which generated intense political instability. In 2001, the new president organised a forum for national reconciliation to address the issues that had polarised the Ivorian people, including the questions of nationality, land ownership, the disputed legitimacy of his government and the conditions of service of the security forces. Following the forum, four core Ivorian leaders issued a communiqué in which, among other things, they agreed to oppose undemocratic avenues to power and to create a broad-based national electoral commission. The leaders also agreed to form a new government of national unity. These steps towards national reconciliation and reducing tensions in Côte d'Ivoire were, however, strongly disrupted by the crisis of September

31 UN http://www.un.org/Depts/dpko/missions/unmee/background.html 17 Jul.

32 SC Resolution 1312, 31 July 2000, at par 1.

33 SC Resolution 1741, 30 January 2007.

34 SC Resolution 1312, 31 July 2000.

35 SC Resolution 1320, 15 September 2000. 
2002, with among other things, its attacks on military installations, burning downs of dwellings and the displacement of people. ${ }^{36}$

The ECOWAS Contact Group on Côte d'Ivoire began mediation efforts in September 2002, leading to a cessation of the hostilities and negotiations on a political agreement between the fighting parties. The peace talks finally led to the establishment an ECOWAS Peace Force for Côte d'Ivoire and an appeal to the African Union and the United Nations to further assist ECOWAS to resolve the Ivorian crisis. ${ }^{37}$ The appeal was followed by the French initiative to organise a roundtable, in January 2003 resulting in the signing of the Linas-Marcoussis Agreement. The agreement included the creation of a government of national reconciliation, that would have to prepare a timetable for credible and transparent national elections and would have to take care of, among other things, the creation of a human rights commission consisting of representatives from all parties, the drawing up of a voters roll, the independence of the justice system with respect to electoral disputes, and the implementation of a land tenure regime. ${ }^{38}$

The Linas-Marcoussis Agreement also expressed the wish to UN support. In response to that request, in May 2003, the UN Security Council decided to establish a United Nations Mission in Côte d'Ivoire (MINUCl). ${ }^{39}$ The mission had as its mandate, in short, to facilitate the implementation of the LinasMarcoussis Agreement. Already in February 2004, however, the UN Security Council decided to establish its successor: the United Nations Operation in Côte d'Ivoire (UNOCl). ${ }^{40}$ Its mandate included the monitoring of the 2003 agreement and peace and security issues linked to that. ${ }^{41}$ Further to that, the UNOCI mandate - as of now extended until 30 June $2007^{42}$ - provides for the following tasks:

UN http://www.un.org/Depts/dpko/missions/minuci/background.html 17 Jul. Ibid.

Ibid.

SC Resolution 1479, 13 May 2003.

SC Resolution 1528, 27 February 2004.

Ibid at par 6, a-j.

SC Resolution 1739, 10 January 2007. 
- to facilitate the free flow of people, goods and humanitarian assistance $(\ldots)$;

- to facilitate (...) the re-establishment by the Government of National Reconciliation of the authority of the state throughout Côte d'Ivoire;

- to provide oversight, guidance and technical assistance to the Government of National Reconciliation (...) to prepare for and assist in the conduct of free, fair and transparent electoral processes linked to the implementation of the Linas-Marcoussis Agreement, in particular the presidential election;

- to contribute to the promotion and protection of human rights in Côte d'Ivoire with special attention to violence committed against women and girls, and to help investigate human rights violations with a view to help ending impunity;

- to promote understanding of the peace process and the role of $\mathrm{UNOCI}$ among local communities and the parties, through an effective public information capacity, including the establishment as necessary of a UN radio broadcasting capability;

- to assist the Government of National Reconciliation (...) in restoring a civilian policing presence throughout Côte d'Ivoire, and to advise the Government of National Reconciliation on the restructuring of the internal security services;

- to assist the Government of National Reconciliation (...) in reestablishing the authority of the judiciary and the rule of law throughout Côte d'Ivoire.

Since 2004, the mandate is still basically the same, although it now also includes such issues as:

- to contribute (...) to the security of the operations of identification of the population and registration of voters (...);

- to contribute (...) to the security of the areas where voting is to take place; 
- to provide (...) for logistical support for the Independent Electoral Commission, in particular for the transportation of electoral material. ${ }^{43}$

\subsubsection{Sudan (UNAMIS/UNMIS, 2004 - )}

Sudan became independent in 1956 and has had many conflicts since then. The recently ended north-south civil war began in 1983. For about two decades, the government and the Sudan People's Liberation Movement/Army (SPLM/A), the main rebel movement in the south, fought over resources, power, the role of religion in the state, and self-determination. Over two million people died, four million were uprooted and some 600,000 people fled the country as refugees. In July 2002, the parties to the conflict signed the 'Machakos Protocol', in which they reached a specific agreement on a broad framework, setting forth the principles of governance, the transitional process and the structures of government, as well as, among other things, on the right to self-determination for the people of South Sudan. The parties agreed to continue talks on the outstanding issues of power sharing, wealth sharing, human rights and a ceasefire. ${ }^{44}$

Supporting the outcome of the peace process, the UN Security Council decided in June 2004 to establish a political mission, called the United Nations Advance Mission in the Sudan (UNAMIS). ${ }^{45}$ The mission was mandated, among other things, to prepare for the introduction of a peace support operation. ${ }^{46}$ As a response to the escalating crisis in Darfur the UN Security Council decided to assign additional tasks to UNAMIS, alongside the leading role the African Union played in the negotiations on a political solution to the conflict. ${ }^{47}$ In January 2005, the government of Sudan and the SPLM/A signed a peace agreement, related to, among other things, outstanding issues remaining after the Machakos Protocol. It included provisions on security arrangements, powersharing in the capital of Khartoum, some autonomy for the south, and more

43 SC Resolution 1739, 10 January 2007, at par 2 (j).

44 UN http://www.un.org/Depts/dpko/missions/unmis/background.html 17 Jul.

45 SC Resolution 1547, 11 June 2004.

46 UN http://www.un.org/Depts/dpko/missions/unmis/background.html 17 Jul.

47 SC Resolution 1556, 30 July 2004. 
equitable distribution of economic resources, including oil. ${ }^{48}$ The Chapeau to the agreement states that the parties are committed -

to a negotiated settlement on the basis of a democratic system of governance which, on the one hand, recognizes the right of the people of Southern Sudan to self-determination and seeks to make unity attractive during the Interim Period, while at the same time [it] is founded on the values of justice, democracy, good governance, respect for fundamental rights and freedoms of the individual, mutual understanding and tolerance of diversity within the realities of the Sudan. ${ }^{49}$

Further to that, it was stated that the successful implementation of the agreement "shall provide a model for good governance in the Sudan". ${ }^{50}$

In March 2005 the UN Security Council decided to establish the United Nations Mission in the Sudan (UNMIS). ${ }^{51}$ The operation incorporates the tasks performed by UNAMIS and has a mandate - as of now extended until 31 October $2007^{52}$ - to support the implementation of the peace agreement, et cetera, but also:

- to assist the parties to the Comprehensive Peace Agreement, in addressing the need for a national inclusive approach, including the role of women, towards reconciliation and peacebuilding;

- to assist the parties to the Comprehensive Peace Agreement (...) in restructuring the police service in Sudan, consistent with democratic policing, to develop a police training and evaluation programme, and to otherwise assist in the training of civilian police;

- to assist the parties to the Comprehensive Peace Agreement in promoting the rule of law, including an independent judiciary, and the protection of human rights of all people of Sudan (...);

48 Ibid.

49 ReliefWeb http://www.reliefweb.int/ 17 Jul.

50 Ibid.

51 SC Resolution 1590, 24 March 2005.

52 SC Resolution 1755, 30 April 2007. 
- to provide guidance and technical assistance to the parties to the Comprehensive Peace Agreement (...) to support the preparations for and conduct of elections and referenda provided for by the Comprehensive Peace Agreement.

In August 2006 the UN Security Council decided to expand the mandate of UNMIS to Darfur, in order to support implementation of the Darfur Peace Agreement of May 2006 and the N'djamena Agreement on Humanitarian Cease-fire on the Conflict in Darfur. ${ }^{53}$ The mandate since then includes, among other things, the tasks:

- to assist the parties (...) in the preparations for and conduct of referendums provided for in the Darfur Peace Agreement;

- to assist the parties to the Darfur Peace Agreement in promoting the rule of law, including an independent judiciary, and the protection of human rights of all people of the Sudan through a comprehensive and coordinated strategy with the aim of combating impunity and contributing to long-term peace and stability and to assist the parties to the Darfur Peace Agreement to develop and consolidate the national legal framework.

\subsection{The six mandates under a good governance lens}

In the present section, the notions of good governance as elaborated upon in the introductory chapter of this paper will be linked to the descriptions of the six mandates as performed in the previous section.

\subsubsection{Western Sahara}

The mission in Western Sahara is even at first sight a 'good governance mission', although at its beginning (in 1991) the words 'good governance' were not yet very common, at least not in peace and security circles. In the results

53 SC Resolution 1706, 31 August 2006, at par 1, refers to par 8, 9 and 12 as new elements of the mandate. 
the mission aims for, one can see many of the good governance elements as discussed in section one, especially under the labels of 'participation', 'consensus oriented' (that is to say: trying to find a way out, while "balancing different interests in society to reach a broad consensus in society", but not necessarily leading to a real consensus; that is also part and parcel of referenda), 'accountability' (choosing for a system in which the government "is accountable to those who will be affected by its decisions or actions"), 'transparency' (decision-making, based on information that is "freely available and directly accessible"), 'equity and inclusiveness' (ensuring that all persons belonging to the Western-Sahara people "feel that they have a stake [in the referendum] and do not feel excluded"), and finally: 'the rule of law' (accept the outcome of the referendum, while in the (long) process of working towards it, enforcing the (legal) rules of the games impartially, with respect for such human rights as freedom of expression, the right not to be detained for political reasons, et cetera).

Also the other elements, mentioned before, such as taking care that the future government will be "responsive to the present and future needs of society" are clearly part of the mission's task. The latter is closely related to a right which is generally seen as either a right that belongs to the human rights codex or as a collective right that precedes individual human rights: the right to selfdetermination of peoples. It should be noted that the right to self-determination has been recognised in a series of UN documents and legal instruments, amongst other things, in common article 1 to the 1966 UN Covenants on Civil and Political Rights and on Economic, Social and Cultural Rights. It is also considered to be a right with a peremptory character, as affirmed in case law by the International Court of Justice (ICJ). ${ }^{54}$

\subsubsection{Liberia}

The UN peacekeeping operation in Liberia is also in many ways a good governance operation, although a bit less explicitly and detailed as is the case

54 See eg the case on East-Timor, Portugal $v$ Australia ICJ Reports 1995, 102. On the legal character of the right to self-determination, see Crawford State Responsibility 246-247. 
with the operation in Western Sahara. Nevertheless, elements such as 'participation' are reflected in the issue of the assistance of the government as to the preparation of national elections (although it should be observed that even free and fair elections do not necessarily lead to good and equitable participation in the governments afterwards). Notions as the ones on transparency and responsiveness are reflected in, among other things, the mandate to assist the transitional government of Liberia in monitoring and restructuring the police force of Liberia "consistent with democratic policing", while issues such as effectiveness and efficiency can be found back in the mandate to assist the government in the re-establishment of national authority throughout the country, "including the establishment of a functioning administrative structure at both the national and local levels" and in words such as "developing a strategy to consolidate governmental institutions".

Further to this, there is quite some attention in the mandate of the Liberian peacekeeping operation for the rule of law ("consolidate (...) a national legal framework and judicial and correctional institutions") and for human rights, including the rights of vulnerable groups (such as refugees and internally displaced persons, women, children, and demobilised child soldiers).

Finally, in relation to Liberia it is worth recalling that according to UNESCAP "the concept of efficiency in the context of good governance also covers the sustainable use of natural resources (...)". The (ab)use of natural resources, still being a major issue in Liberia, is covered within the mandate of the UN operation by the task "to assist the transitional government in restoring proper administration of natural resources".

\subsubsection{Democratic Republic of the Congo}

As is the case with Liberia, the UN operation in the Congo is first of all a peace and security mission. Nevertheless, in the case of the Congo as well, it is clear that the UN Security Council is convinced that a standstill in the hostilities is only a part of the larger scene, including the need of establishing sustainable governance structures, based upon respect for underlying core values. Notions 
such as participation can be found in the mandate lines on contributing to "the successful completion of the electoral process" and "assisting in the establishment of a secure environment for free, transparent and peaceful elections to take place", while the effectiveness and efficiency of core tasks of the government, in casu performing its police and defence tasks, are reflected in such notions as "to contribute to arrangements taken for the security of the institutions and the protection of officials of the Transition in Kinshasa", "assist the Congolese authorities in the maintenance of order in other strategic areas" and "security sector reform, including the integration of national defence and internal security forces".

It is also interesting to observe from a good governance perspective that the mandate speaks of training and monitoring the police, "while ensuring that they are democratic and fully respect human rights and fundamental freedoms". Further to this the human rights issue is again mentioned in relation to vulnerable groups, while the mandate also speaks of assisting "in the voluntary return of refugees and internally displaced persons". That is an issue of refugee law as well as human rights law. The rule of law, finally, is reflected in such notions as providing "advice and assistance to the transitional government and authorities, as to essential legislation, including the future constitution".

\subsubsection{Ethiopia and Eritrea}

Although several other ongoing UN peacekeeping operations in Africa are dealing with transboundary issues, the operation in Ethiopia and Eritrea is the only one to deal with a real inter-state (border) conflict. And where the core of the mandate relates to the cessation of the hostilities, the governance structures of both parties are not addressed. The mandate speaks of the task "to coordinate the Mission's activities (...) with humanitarian and human rights activities of the United Nations and other organizations in those areas", but that is more a governance issue related to the UN operation itself than to the warring parties. 


\subsubsection{Côte d'Ivoire}

Having a look at the mandate of the UN operation in Côte d'Ivoire through a good governance lens, it should be clear again that UNOCI is first of all a peace and security operation, trying to reach a stand still in the hostilities. In terms of governance relevance, it is important to underline, however, that the mandate also stresses the need of re-establishing "the authority of the State throughout Côte d'Ivoire", of supporting the government as to the organisation of "free, fair and transparent elections", of respect for human rights for the future as well as during the operation, the promotion of "understanding of the peace process (...) through an effective public information capacity", of "restoring a civilian policing presence throughout Côte d'Ivoire", and last but not least, of "re-establishing the authority of the judiciary and the rule of law throughout Côte d'Ivoire". Taking the UNESCAP criteria, one can again see that most of them are present in the UNOCl's mandate, although some more explicitly (such as the rule of law) and others more implicitly (such as participation and the consensus orientation). It is clear, however, that the latter criteria are also very central to the UN approach to Côte d'Ivoire. The terminology used in the mandate strongly relates to the history of the conflict and the terms used by the Côte d'Ivoirian government and the other parties involved, but the core message remains the same: how to create governance structures for the long run, in order to establish a stable Côte d'Ivoire, which is able to overcome future problems by democratic, non-military means.

\subsubsection{Sudan}

To what extent is the mandate of UNMIS related to (good) governance? Although the mandate does not use the word 'governance', several parts of it are overlapping with the good governance criteria as used in this paper. One can think of such elements as assisting the parties to the peace agreement "in restructuring the police service in Sudan, consistent with democratic policing, to develop a police training and evaluation programme, and to otherwise assist in the training of civilian police", assisting the parties "in promoting the rule of law, including an independent judiciary, and the protection of human rights of all people of Sudan through a comprehensive and coordinated strategy with the 
aim of combating impunity and contributing to long-term peace and stability and to assist the parties to the Comprehensive Peace Agreement to develop and consolidate the national legal framework", ensuring "an adequate human rights presence, capacity, and expertise within UNMIS to carry out human rights promotion, civilian protection, and monitoring activities", providing "guidance and technical assistance (...) to support the preparations for and conduct of elections and referenda provided for by the Comprehensive Peace Agreement", contributing towards -

international efforts to protect and promote human rights in Sudan, as well as to coordinate international efforts towards the protection of civilians with particular attention to vulnerable groups including internally displaced persons, returning refugees, and women and children (....).

The expansion of the mandate to Darfur in August 2006 also clearly relates to several good governance elements. It will do to recall notions such as assisting the parties "in the preparations for and conduct of referendums provided for in the Darfur Peace Agreement" and "in promoting the rule of law, including an independent judiciary". Further to that the mandate of the operation includes the task to assist the parties "to develop and consolidate the national legal framework" and as to "the protection of human rights of all people of the Sudan through a comprehensive and coordinated strategy with the aim of combating impunity and contributing to long-term peace and stability". The latter is a good governance notion par excellence.

\section{Reflections upon the changing nature of peacekeeping operations}

\subsection{Introduction}

As is shown in the description and analysis of the six African cases, UN peacekeeping operations are about much more than strict peace and security elements only. They time and again refer to good governance related issues, from literally working towards building up a stable and accountable government to the taking into consideration of core values underlying it, especially respect for human rights and the systematic inclusion of minority perspectives in 
decision-making. The present section further reflects and elaborates upon this trend.

\subsection{Rwanda and the pressure to create new mandates}

It was mentioned that UN peacekeeping in the 1990s was confronted with some dramatic failures. Two of these operations, generally considered to be black pages in the UN history of peacekeeping, ${ }^{55}$ related to Africa: the operations in Somalia (UNOSOM I and II, April 1992- March 1995) and Rwanda (UNAMIR, October 1993-March 1996). It would be beyond the scope of this paper to discuss them systematically, but given the scope it would be good to try to learn some good governance related lessons. These lessons can be drawn, for instance, from the work of the Independent Inquiry Commission that was given the task by the UN to scrutinise the UN actions during the 1994 Rwandese genocide. ${ }^{56}$ Although its mandate nor its approach related to, technically speaking, governance issues in a narrow sense, it is clear that the Rwandese 'non-operation' has made visible on the deepest level one can imagine what the operation should have been all about. In the words of the Inquiry Commission:

While the presence of United Nations peacekeepers in Rwanda may have begun as a traditional peacekeeping operation to monitor the implementation of an existing peace agreement, the onslaught of the genocide should have led decision-makers in the United Nations from the Secretary-General and the Security Council to Secretariat officials and the leadership of UNAMIR - to realize that the original mandate, and indeed the neutral mediating role of the United Nations, was no longer adequate and required a different, more assertive response, combined with the means necessary to take such action.

Although the word governance is not used by the Inquiry Commission, it should be clear that this is what it is all about: changing governance structures and tactics in order to protect innocent (and less innocent) people against their

55 See, ia, on the intervention in Rwanda: Dallaire Shake Hands with the Devil; and on Somalia: Walter Clark and Herbst (eds) Learning from Somalia.

56 Commission chaired by Ingvar Carlsson from Sweden. UN Doc S/1999/1257, 16 December 1999.

57 Ibid IV at par 19. 
governments and against one another, and to help creating interim situations as well as more durable structures, in which populations can survive firstly and subsequently, dare to think in terms of future perspectives. Or in terms of this paper: good governance structures, all elements included. In relation to UNAMIR, it was observed in a recent PhD thesis that the policy tools Rwanda was desperately in need of - such as verification of human rights violations, the organisation of elections and election monitoring - were not even included in UNAMIR's mandate, and that "the genocide could take place when good governance was nowhere to be found". ${ }^{58}$ That is in a few words one of the core lessons to be learnt - and that has been learned - from the crisis in Rwanda. In this respect, Rwanda has not been an exclusive case, but together with for instance the UN Peacekeeping operation in Bosnia (UNPROFOR 1992-1995) it urged new ways of thinking.

\subsection{The character of the (African) conflicts to be addressed}

Before elaborating upon these 'new ways of thinking' it would be good to spend a few additional words upon the conflicts the UN peacekeeping operations in Africa have to address. In this paper's section on the present six UN operations many specific characteristics of the ongoing conflicts have been mentioned. Further to that, however, it would be important to keep in mind that in many African cases, leading to peacekeeping operations, almost everything is at stake that can be problematic. Many African cases show a multitude of factors that should in fact be addressed simultaneously, knowing otherwise that the outcome of the operations will never be satisfactory. As a matter of fact the descriptions and analyses of the six African cases have already given much evidence of that.

In a recent article, Crispin Grey-Johnson, representative of Gambia to the UN, states that experts have identified three clusters of factors that give rise to conflict, viz, root or structural, proximate and triggers: 
Structural factors relate to issues of governance and the functioning of State with regard to its relationship with the citizenry, legitimacy, ability to provide basic services and mode of governance. They manifest themselves in weak or overly strong autocratic governments, rampant inequities among the population, corruption, discrimination, extreme poverty and deprivation, human rights deficiencies and a weakened system of adjudication. These cause disaffection among the population, which could eventually lead to uprisings, insurgencies and violent confrontation with established authority.

Proximate factors differ only by degree from structural causes. When discrimination becomes legitimized in the promulgation of laws that target a particular ethnic group, religion or clan, or if there is a precipitous decline in the standard of living, the conditions of conflict become heightened.

These factors are one step removed from the triggers of conflict. There are sudden social traumas that spark off hostilities. In Rwanda, for example, there were many elements in the relationship between the Hutus and Tutsis that constituted structural and proximate causes of violence, but it took the shooting down of the presidential aircraft to trigger off the genocide. ${ }^{59}$

In Grey-Johnson's words "a typical African country in conflict is poor, with weak government and public institutions, a small private sector, high illiteracy, a narrow skills base and limited capabilities for guaranteeing security", and that state of affairs "is rendered even more dire by civil strife, whose effects on the economy and the society at large are debilitating", while -

the situation after the conflict is one of destruction: infrastructure destroyed; basic services, water and fuel supplies, and electricity disrupted or lost; and transportation system barely functioning. Many professional and skilled personnel would very likely have left the country, thus severely circumscribing the ability of institutions to function. ${ }^{60}$

And "even where the structures and institutions of democracy do exist, they are usually weak and unable to sustain the workings of a democratic system". ${ }^{61}$ Grey Johnson is no doubt right as to his observations on Africa, although one

59 Grey-Johnson 2006 UN Chronicle http://www.un.org/ 7Jul.

60 Ibid.

61 Ibid. 
should not forget that all these phenomena are not exclusively African. And even if there would be a typical African set of problems the solutions to these problems would not be typically African.

\subsection{From peacekeeping to building stable governance structures}

Apart from being failures in themselves, (non-)operations like the ones in Somalia and Rwanda have strongly undermined the authority and credibility of the UN in the field of peacekeeping operations. Also in response to that, the UN started a systematic reflection upon the failures. One of the first expressions of that reflection have been presented in Boutros Boutros-Ghali's An Agenda for Peace (1995), which was in theory a supplement to the 1992 An Agenda for Peace, but was in practice to be seen as shaking up the world after the disasters in the field of peacekeeping operations of the early and mid 1990s. While the 1992 Agenda was written in an optimistic spirit after the fall of the Berlin Wall and the collapse of the Soviet-Union, symbolised amongst other things by the fact that the UN Security Council for the first time met at the level of heads of states or government (in its famous session of 31 January 1992), ${ }^{62}$ the 1995 Agenda was full of the new sense of reality. See the way this has been worded in the introduction to the 1995 Agenda:

[When the Security Council met in January 1992] the cold war had ended. It was a time of hope and change and of rising expectations for - and of - the United Nations. (...) Since the Security Council Summit, [however], the pace has accelerated. There have been dramatic changes in both the volume and the nature of the United Nations activities in the field of peace and security. New and more comprehensive concepts to guide those activities, and their links with development work, are emerging. Old concepts are being modified. There have been successes and there have been failures. The Organization has attracted intense media interest, often laudatory, more often critical, and all too often focused on only one or two of the many peace-keeping operations in which it is engaged, overshadowing other major operations and its vast effort in the economic, social and other fields. ${ }^{63}$ 
These very illustrative introductory words were followed by a range of observations, in which the disastrous operations of the 1990s are used to sharpen the focus of the UN peacekeeping operations. Some of these observations are relevant from the point of view of the good governance scope of the present paper. After having observed that "the new breed of intra-state conflicts have certain characteristics that present United Nations peacekeepers with challenges not encountered since the Congo operation of the early 1960s", that these conflicts are "usually fought not only by regular armies but also by militias and armed civilians with little discipline and with ill-defined chains of command", and that "civilians are the main victims and often the main targets", the 1995 Agenda states that "the combatant authorities, in so far as they can be called authorities, lack the capacity to cope with them". ${ }^{64}$ The Agenda then adds that -

another feature of such conflicts is the collapse of state institutions, especially the police and judiciary, with resulting paralysis of governance, a breakdown of law and order, and general banditry and chaos. Not only are the functions of government suspended, its assets are destroyed or looted and experienced officials are killed or flee the country. This is rarely the case in inter-state wars. It means that international intervention must extend beyond military and humanitarian tasks and must include the promotion of national reconciliation and the re-establishment of effective government. ${ }^{65}$

The 1995 Agenda successively discusses the instruments that would be available to the UN to do all this - such as preventive diplomacy and peacemaking, peace-keeping, post-conflict peace-building, disarmament, sanctions, and enforcement action - before concluding as follows:

The times call for thinking afresh, for striving together and for creating new ways to overcome crises. This is because the different world that emerged when the cold war ceased is still a world not fully understood. The changed face of conflict today requires us to be perceptive, adaptive, creative and courageous, and to address simultaneously the immediate as well as the root causes of conflict, which all too often lie in the absence of economic opportunities and social inequities. Perhaps above all it requires a deeper commitment 
to cooperation and true multilateralism than humanity has ever achieved before. $^{66}$

These words can be seen as realistic and prophetic at the same time. At the UN level they have been succeeded five years later by a thorough analysis of the UN peacekeeping system and practice by the Panel on United Nations Peace Operations, the previously mentioned 'Brahimi report'. ${ }^{67}$ The Panel report criticises the often vague mandates of the Security Council, sending out poorly armed and trained soldiers, the inadequate financing and numbers of personnel, the inadequate planning, and the mismanagement in the field, et cetera $^{68}$ but also contains constructive recommendations in the field of preventive action and peace-building strategies. In the latter field, the report comes up with a series of observations, some of which are directly relevant for the core of the present paper, for instance the one on elections:

(...) 'free and fair' elections should be viewed as part of broader efforts to strengthen governance institutions. Elections will be successfully held only in an environment in which a population recovering from war comes to accept the ballot over the bullet as an appropriate and credible mechanism through which their views on government are represented. Elections need the support of a broader process of democratization and civil society building that includes effective civilian governance and a culture of respect for basic human rights, lest elections merely ratify a tyranny of the majority or be overturned by force after a peace operation leaves. ${ }^{69}$

The same goes for the recommendation on police forces and the rule of law:

(...) United Nations civilian police monitors are not peacebuilders if they simply document or attempt to discourage by their presence abusive or other unacceptable behaviour of local police officers - a traditional and somewhat narrow perspective of civilian police capabilities. Today, missions may require civilian police to be tasked to reform, train and restructure local police forces according to international standards for democratic policing and human rights, as well as having the capacity to respond effectively to civil disorder and for self-defence. ${ }^{70}$ 
And for the recommendation on embedding human rights into peacekeeping operations:

(...), the human rights component of a peace operation is indeed critical to effective peace-building. United Nations human rights personnel can play a leading role, for example, in helping to implement a comprehensive programme for national reconciliation. The human rights components within peace operations have not always received the political and administrative support that they require, however, nor are their functions always clearly understood by other components. Thus, the Panel stresses the importance of training military, police and other civilian personnel on human rights issues and on the relevant provisions of international humanitarian law. ${ }^{71}$

These observations do lead to a set of 'key recommendations', amongst which one can find the following governance related wordings:

The Panel recommends a doctrinal shift in the use of civilian police, other rule of law elements and human rights experts in complex peace operations to reflect an increased focus on strengthening rule of law institutions and improving respect for human rights in postconflict environments. ${ }^{72}$

The tone has thus been set by the Agenda for Peace and the Brahimi report, one might say. Their approach can be found back and is elaborated upon in a huge number of UN core documents, amongst others - and not the least - in the 2005 September Word Summit Outcome document ${ }^{73}$ and Kofi Annan's In larger freedom: towards development. Security and human rights for all, ${ }^{74}$ written in preparation of the World Summit. Kofi Annan's document, after having underlined the importance of "transparent, accountable systems of governance, grounded in the rule of law, encompassing civil and political as well as economic and social rights, and underpinned by accountable and efficient public administration", ${ }^{75}$ contains, amongst other things, the proposal

71 Ibid at par 41.

72 Ibid at par 47 (b).

73 UN Doc A/RES/60/1, 24 October 2005.

74 UN Doc A/59/2005, 21 March 2005.

75 Ibid at par 36. 
to establish a Peacebuilding Commission. That proposal is grounded in deep awareness of the need to establish stable and sustainable institutions after conflict:

Our record of success in mediating and implementing peace agreements is sadly blemished by some devastating failures. Indeed, several of the most violent and tragic episodes of the 1990s occurred after the negotiation of peace agreements - for instance in Angola in 1993 and in Rwanda in 1994. Roughly half of all countries that emerge from war lapse back into violence within five years. These two points drive home the message: if we are going to prevent conflict we must ensure that peace agreements are implemented in a sustained and sustainable manner. Yet at this very point there is a gaping hole in the United Nations institutional machinery: no part of the United Nations system effectively addresses the challenge of helping countries with the transition from war to lasting peace. ${ }^{76}$

The Peacebuilding Commission would have to be active in the immediate aftermath of wars, in order to

...improve United Nations planning for sustained recovery, focusing on early efforts to establish the necessary institutions (...). ${ }^{77}$

Further to that, it would have to "provide a forum in which the United Nations, major bilateral donors, troop contributors, relevant regional actors and organizations, the international financial institutions and the national or transitional Government of the country concerned can share information about their respective post-conflict recovery strategies $(\ldots)^{\prime \prime}$, while it also would have to "extend the period of political attention to post-conflict recovery". ${ }^{78}$ In addition, it would be important, according to In larger freedom,

...if UN Member States could at any stage make use of the Peacebuilding Commission's advice and could request assistance from a standing fund for peacebuilding to build their domestic institutions for reducing conflict, including through strengthening the rule-of-law institutions. ${ }^{79}$ 
Presenting it this way, there are many links to the concept of good governance.

The UN Member States' meeting at the occasion of the $60^{\text {th }}$ Birthday of the UN, indeed decided to establish a Peacebuilding Commission "as an intergovernmental advisory body", ${ }^{80}$ focusing "attention on the reconstruction and institution-building efforts necessary for recovery from conflict and support the development of integrated strategies in order to lay the foundation for sustainable development". ${ }^{81}$ In addition, the commission should -

...provide recommendations and information to improve the coordination of all relevant actors within and outside the United Nations, develop best practices, help to ensure predictable financing for early recovery activities and extend the period of attention by the international community to post-conflict recovery. ${ }^{82}$

Although the word(s) '(good) governance' are not used, it is clearly and basically about nothing else.

Shortly after the summit, the UN General Assembly effectively established the Peacebuilding Commission. ${ }^{83}$ It is composed of seven members selected by the Security Council (as of now including South-Africa), seven members elected by the UN Economic and Social Council (as of now including Angola (also elected as Chair) and Guinea-Bissau), five "top providers of assessed contributions to United Nations budgets and of voluntary contributions to the United Nations funds, programmes and agencies, including a standing peacebuilding fund" (as of now including The Netherlands), five "top providers of military personnel and civilian police to United Nations missions" (as of now including Bangladesh, Ghana and Nigeria), and seven members elected by the General Assembly (as of now including Burundi). ${ }^{84}$ Thirty-one members in total, but they are supposed to meet (and are actually meeting) "in various configurations", as the establishing resolution, following the World Summit

80 UN Doc A/RES/60/1, 24 October 2005, at par 97.

81 Ibid at par 98.

82 Ibid.

83 A/RES/60/180, 30 December 2005.

84 Id and UN http://www.un.org/peace/peacebuilding/membership.shtml 17 Jul. 
Outcome document, states. ${ }^{85}$ In the meantime, the commission is operating, focusing so far as its country specific meetings are concerned upon two African States: Burundi and Sierra-Leone. ${ }^{86}$

The Peacebuilding Commission can be seen as one of the bridges between good intentions and daily peacekeeping reality, practicing many of the thoughts and recommendations put forward in the Brahimi report. Apart from the installment of this new body, however, practice has already changed since the mid 1990s, anticipating upon 'the spirit of Brahimi', one might say. Since the major failures, the UN Security Council started paying in a more systematic way attention to humanitarian and human rights issues, even leading to some operations in which the military component became less relevant and in which civilian specialists on human rights, humanitarian law, constitutional law and elections are given a dominant presence. As to the latter, one can think of the UN operation in Kosovo (1999 until present). ${ }^{87}$ Working closely with Kosovo's leaders, the mission as a matter of fact performs the whole spectrum of essential administrative functions and services covering such areas as health and education, banking and finance, post and telecommunications, and law and order. $^{88}$

In the actual performance of the African operations as discussed in this paper, the influence of the Brahimi report is also strongly visible. In 2006, the Dutch Major General Patrick C Cammaert, Commanding the Eastern Division of MONUC in the DRC, was asked by Tilburg University to reflect upon changes in UN peacekeeping after the Brahimi report. His observations from the field deserve serious attention:

The Brahimi report underscored the necessity of multi-dimensional missions. Therefore, as an initial step in the process of establishing a peacekeeping operation, United Nations Head Quarters in New York sets up an Integrated Mission Task Force, which includes expertise

A/RES/60/180, 30 December 2005, at par 3.

86 For a short overview of activities so far, see UN http://www.un.org/peace/peacebuilding/ 17 Jul.

87 SC Resolution 1244, 10 June 1999.

88 UN http://www.unmikonline.org/intro.htm $17 \mathrm{Jul}$. 
from the various components of the UN system such as: the Military, Political, Rule of Law, Human Rights, Child Protection, Administration, Public Information (...). In essence UN forces can only be effective if their activities are planned, coordinated and echeloned into a Mission area of responsibility in a complementary manner (...). It is crucial that the various components communicate and work hand in hand. The components should understand that they are mutually dependant and should work together, through information sharing, particularly in areas such as how to protect the force, protection of civilians under imminent threat, investigations of human rights violations, etc. ${ }^{89}$

And specifically in relation to MONUC:

In MONUC, the military component and the human rights division work closely together not only at the level of the Head Quarters in Kinshasa but also in the field (MONUC has some 15 field offices across the country with a total of 110 Human Rights Officers). Military operations are always planned in close collaboration with our human rights colleagues to engage spoilers of the peace and electoral process as well as violators of human rights. Military operations usually result in a displacement of villagers who are then in need of shelter, food, medical care, security, etc. To effectively address this fall-out is yet another task of MONUC. The military component is also mandated to ensure the protection and security of the Human Rights Officers who are investigating the abuses. Our force has sustained casualties in some tragic circumstances whilst escorting civilian human rights colleagues doing their work - all part of our military business but a frustrating part nonetheless. ${ }^{90}$

As observed by Cammaert in daily practice, since the Brahimi report has been published the UN Secretariat is playing an increasing role in the analysis, design, organisation and leadership of the operations, including a focus upon a better preparation of the military and civilian means provided by the member states. The staff of the Department of Peacekeeping Operations has since the beginning of the Millennium been extended by almost $50 \%$, especially the subdepartments of the military advisor, the civilian police and training particularly benefiting from this. ${ }^{91}$ 
Further to this, it is relevant to mention that the previously discussed 2005 UN Summit document touches upon "the importance of contributions to peace and security by regional organizations and of forging predictable partnerships and arrangements between the United Nations and regional organizations", thereby "noting in particular, given the special needs of Africa, the importance of a strong African Union". ${ }^{92}$ During the last decade, African lead nations and African organisations have been strongly reflecting upon their roles in peacekeeping at the African continent. ${ }^{93}$ In the words of Jakkie Cilliers: "Africa is (...) experiencing a revival of the belief that peace enforcement can best be conducted outside of the UN framework by regional groupings of the willing". ${ }^{94}$ These African states and organisations also know, however, that until now, they often have not been able to fulfil the high expectations they are confronted and confronted themselves - with, and that, especially given the complexities of the situations to deal with, acting without close cooperation with the UN would not be very realistic. ${ }^{95}$

\section{$5 \quad$ Summary and concluding observations}

Crispin Grey-Johnson, the Gambian representative to the UN quoted before, observes that

by giving too much prominence to security responsibilities that need a military predominance in UN peace operations, the requirements for reconstruction, rehabilitation and relaunching of democratic and economic development processes are downplayed and become unresponsive to the need for recovery and the functioning of basic infrastructure and government services. ${ }^{96}$

Wording the problems this way, he is touching upon the core issue of this paper. A focus upon military aspects might be needed and might even have to

92 UN Doc A/RES/60/1, 24 October 2005, at par 93.

93 See eg Malan Peacekeeping in Africa; De Coning 2002 Conflict Trends 46-56; Samii Peace Operations in Africa; Anon 2004 Strategic Comments.

94 Cilliers 2003 African Security Review.

95 Anon 2004 The Economist http://www.economist.com/ 12 Jul at 46.

96 Grey-Johnson supra n 59. 
be given priority, depending on the concrete situation, but if it is not incorporated in a broader analysis of the situation and in a full range of measures and activities, UN peacekeeping operations will never contribute or ultimately lead to stable solutions. Conflicts will reoccur as soon as the operations have ended, for instance because temporarily side-lined leaders will again take up their weapons or will start supporting new generations of rebels, telling them what kind of injustice is done to them.

In this paper it is shown that the times are changing and that the (desirability of) military predominance in UN peace operations is not so clear anymore. Discussing the six ongoing UN peacekeeping operations in Africa, it is shown that in most cases, despite differences, a clear 'second focus' upon good governance issues, as framed in this paper, has been inserted in or added to the mandates.

The presentation and discussion of the six mandates was followed by a further reflection upon trends in UN peacekeeping that have occurred after the major failures of the 1990s. In that respect, the paper firstly refers to the analysis made of the Rwandese disaster by the Independent Inquiry Commission ("the onslaught of the genocide should have led decision-makers in the United Nations (...) to realize that the original mandate was no longer adequate"); followed by some observations as to the complex situation in many African countries. They are, as Grey-Johnson observes, characterised by poverty, weak public institutions, a small private sector, high illiteracy, a narrow skills base and limited capabilities for guaranteeing security, all this being accompanied by civil strife, while the situation after the conflict is often one of total destruction.

Having thus underlined the complexity of African conflicts, it becomes more clear than ever that the UN is seriously in need of new approaches in peacekeeping land. These ways of thinking about and handling of peacekeeping operations have especially been captured into words by the 1995 Agenda and the 2000 Brahimi report, although it can also be observed that practices were already (slightly) changing some time before the reports 
were published. The reports reflect a good interplay between needs felt on the ground and expressed by military practitioners, and theoretical reflection upon that. Especially the Brahimi report strongly criticises what went wrong in the past, but also comes up with a range of constructive observations and recommendations, inter alia in relation to good governance notions as expressed in this paper. In the words of the panel there should indeed be

a doctrinal shift in the use of civilian police, other rule of law elements and human rights experts in complex peace operations.

In later years, the approach taken by the Brahimi report has been practiced, so to say, although not as a handbook that provide for solutions for all kinds of concrete cases. It serves more as a general source of inspiration, expressing the overall approach that should be followed. Practical translations can be found in some of the (revised) mandates of the six African operations, but also, in a more structural sense, in the strengthening of the UN Department of Peacekeeping Operations and the establishment, in 2005, of the Peacebuilding Commission. Although the word(s) '(good) governance' are not used in the mandate of the Peacebuilding Commission, it is clearly meant to deliver decisive contributions to that. On a practical note it is also observed in the paper that the African Union keeps seeking for a balance between solving African problems of its own and cooperation with, inter alia, the UN. Sometimes it is thought that one could and should do without the UN, but reality so far makes clear that in many problematic situations that would be a problematic route. That is to a large extent related to the complexity of the issues that have to be solved, but also to the lack of leadership and preparedness and ability to transcend the level of daily struggling.

But there is more. Taking into account that all African cases in which the UN assists or intervenes by means of a peacekeeping operation or in which it will have to assist or intervene in the future - have their specific characteristics, it would not be easy to identify a range of factors that have to be taken into account in order to improve the chances of a successful completion of UN missions. There is no simple or uniform recipe. Nevertheless, I would like to 
conclude this paper with three observations that would be relevant for all operations:

- Firstly, take care of the economic root causes of conflicts, including especially the issue of abuse of natural resources. It is the economic dimension of conflicts, which is not discussed in this good governance oriented paper, but which is in many cases of primordial interest.

- Secondly, invest systematically in governmental structures and legal institutions, while seriously training police, army and judiciary staff, in terms of the skills they have to learn and the values they have to take into account while acting. The latter is about respect for the human rights of those they are dealing with, of participation by neglected minorities, of seriously obstructing the standard practice of using violent means to resolve conflicts, but also about corruption and other legitimacy undermining activities.

- Thirdly, take care of a good interplay with local, regional and national governments, and with mixes of state and non-state actors such as land lords and associations of farmers, with regional intergovernmental organisations, with non-governmental organisations, with individual human rights officers, with International Financial Institutions and UN Specialised Organisations, as well as with whatever persons and organisations that might deliver fruitful contributions to ending conflicts and building up sustainable, human rights friendly governance structures.

It should be added in all modesty that there is by far no guarantee that efforts conducted along these lines will be successful. The 'old way', however, is anyhow destined to fail. 


\section{Bibliography}

Anon 2004 Strategic Comments

Anon "African peacekeeping: Revival or relapse?" 2004 (5) Strategic Comments

Alfredson, Clapp and Sano (eds) Human Rights and Good Governance Alfredson G, Clapp R and Sano HO (eds) Human Rights and Good Governance: Building Bridges (Martinus Nijhoff Publishers London 2002)

Cilliers 2003 African Security Review

Cilliers $\mathrm{J}$ "Peacekeeping, Africa and the Emerging Global Security Architecture" 2003 (12) African Security Review 111-114

Clark and Herbst (eds) Learning from Somalia

Clark W and Herbst J (eds) Learning from Somalia: The Lessons of Armed Humanitarian Intervention (Westview Press Oxford 1997)

Copson Democratic Republic of the Congo

Copson RW Democratic Republic of the Congo: Peace Process and Background (Washington CRS Report for Congress 2001)

Crawford State Responsibility

Crawford J The International Law Commission's Articles on State Responsibility (Cambridge University Press Cambridge 2002)

Crispin GJ "Beyond Peacekeeping: The Challenge of Post-Conflict Reconstruction and Peacebuilding in Africa" 2006 UN Chronicle Online Edition 1

Dallaire Shake Hands with the Devil

Dallaire R Shake Hands with the Devil (Carroll \& Graf Publishers New York 2004) 
De Coning 2002 Conflict Trends

De Coning C "Peacekeeping in Africa, the next decade" 2002 (3) Conflict Trends 46-56

Hout Politics of Aid Selectivity

Hout W The Politics of Aid Selectivity: Good Governance Criteria in World Bank, US and Dutch Development Assistance (Routledge London 2007)

Malan Peacekeeping in Africa

Malan M Peacekeeping in Africa: Occasional Paper No 31 (Institute for Security Studies Pretoria 1998)

Samii Peace Operations in Africa

Samii C Peace Operations in Africa: Capacity, Operations, and Implications

Report from the $34^{\text {th }}$ Annual Vienna Peacemaking and Peacekeeping

Seminar (International Peace Academy New York 2004)

Sepulveda et al (eds) Human Rights Reference Handbook

Sepulveda M, Van Banning, T Gudmundsdóttir, GD, Chamoun C and Van Genugten W (eds) Human Rights Reference Handbook $3^{\text {rd }}$ ed (University of Peace Costa Rica 2004)

Van der Lijn Walking the Tightrope

Van der Lijn J Walking the Tightrope: Do UN Peacekeeping operations actually contribute to durable peace? (Rozenberg Publishers Amsterdam 2006)

Van Genugten et al United Nations of the Future

Van Genugten W et al The United Nations of the Future: Globalization with a Human Face (KIT Publishers Amsterdam 2006)

\section{Register of court cases}

Portugal v Australia ICJ Reports 1995 


\section{Register of Internet resources}

Anon 2004 The Economist http://www.economist.com/ 12 Jul

Anon "Can Africans keep their own peace?" 2004 The Economist 46

[Found on internet]

http://www.economist.com/research/articlesBySubject/displaystory.cfm?sub jectid=5189853\&story id=E1 NSSQDGS [Date of use 12 July 2008]

\section{Cammaert http://www.books4life.nl/ 12 Jul}

Cammaert P Lecture, held at the occasion of the presentation of the Max van der Stoel Human Rights Award 2006, Tilburg University, 14 December 2006 [Found on internet]

http://www.books4life.nl/tilburg/LectureCammaert.pdf [Date of use 12 July 2008]

Grey-Johnson 2006 UN Chronicle http://www.un.org/ 7Jul

Grey-Johnson C "Beyond Peacekeeing; The Challenge of Post-Conflict Reconstruction and Peacebuilding in Africa" 2006 (1) UN Chronicle Online Edition [Found on internet] http://www.un.org/Pubs/chronicle/2006/issue1/0106p08.htm\# [Date of use 17 Jul 2008]

ReliefWeb http://www.reliefweb.int/ 17 Jul

ReliefWeb The Comprehensive Peace Agreement between The Government of The Republic of The Sudan and The Sudan People's Liberation Movement/Sudan People's Liberation Army [Found on internet] http://www.reliefweb.int/rw/RWB.NSF/db900SID/EVIU6AZBDB?OpenDocument [Date of use 17 July 2008]

UN http://www.ohchr.org/english/law/index.html 17 Jul

UN How do we make a difference? [Found on internet]

http://www.ohchr.org/english/law/index.html [Date of use 17 July 2008] 
UN http://www.un.org/Depts/dpko/dpko/ $17 \mathrm{Jul}$

United Nations Peacekeeping [Found on internet]

http://www.un.org/Depts/dpko/dpko [Date of use 17 July 2008]

UN http://www.un.org/Depts/dpko/dpko/co mission/unomil.htm 17 Jul

United Nations United Nations Observer Mission In Liberia

UNOMIL (September 1993 September 1997) [Found on internet]

http://www.un.org/Depts/dpko/dpko/co mission/unomil.htm [Date of use 17 July 2008]

UN http://www.un.org/Depts/dpko/missions/minuci/background.html $17 \mathrm{Jul}$ United Nations Côte d'Ivoire - MINUCI - Background [Found on internet] http://www.un.org/Depts/dpko/missions/minuci/background.html [Date of use 17 July 2008]

UN http://www.un.org/Depts/dpko/missions/minurso/mandate.html $17 \mathrm{Jul}$ United Nations Western Sahara - MINURSO - Mandate [Found on internet] http://www.un.org/Depts/dpko/missions/minurso/mandate.html [Date of use 17 July 2008]

UN http://www.un.org/Depts/dpko/missions/minurso/res.html 17 Jul United Nations Western Sahara - MINURSO - UN Documents [Found on internet] http://www.un.org/Depts/dpko/missions/minurso/res.html [Date of use 17 July 2008]

UN http://www.un.org/Depts/dpko/missions/monuc/ $17 \mathrm{Jul}$ United Nations United Nations Organization Mission in the Democratic Republic of the Congo [Found on internet] http://www.un.org/Depts/dpko/missions/monuc/ [Date of use 17 July 2008]

UN http://www.un.org/Depts/dpko/missions/unmil/background.html 17 Jul United Nations Liberia - UNMIL - Background [Found on internet] http://www.un.org/Depts/dpko/missions/unmil/background.html [Date of use 17 July 2008] 
UN http://www.un.org/Depts/dpko/missions/unmis/background.html 17 Jul United Nations Sudan - UNMIS - Background [Found on internet] http://www.un.org/Depts/dpko/missions/unmis/background.html [Date of use 17 July 2008]

UN http://www.un.org/peace/peacebuilding/ 17 Jul United Nations Peacebuilding Commission [Found on internet] http://www.un.org/peace/peacebuilding/ [Date of use 17 July 2008]

UN http://www.un.org/peace/peacebuilding/membership.shtml $17 \mathrm{Jul}$ United Nations Membership and Configurations [Found on internet] http://www.un.org/peace/peacebuilding/membership.shtml [Date of use 17 July 2008]

UN http://www.unescap.org/ $17 \mathrm{Jul}$

United Nations ESCAP What is Good Governance? [Found on internet] http://www.unescap.org/pdd/prs/ProjectActivities/Ongoing/gg/governance.a sp [Date of use 17 July 2008]

UN http://www.unmikonline.org/intro.htm $17 \mathrm{Jul}$ UN Fact Sheet [Found on internet] http://www.unmikonline.org/intro.htm [Date of use 17 July 2008]

\section{List of treaties and international documents}

Independent Inquiry Commission UN Doc S/1999/1257 1999

Report of the Panel on United Nations Peace Operations UN Doc A/55/305 2000

SC Resolution 1020 (10 November 1995)

SC Resolution 1244 (10 June 1999)

SC Resolution 1279 (30 November 1999)

SC Resolution 1291 (24 February 2000)

SC Resolution 1312 (31 July 2000) 
SC Resolution 1320 (15 September 2000)

SC Resolution 1479 (13 May 2003)

SC Resolution 1509 (19 September 2003)

SC Resolution 1528 (27 February 2004)

SC Resolution 1547 (11 June 1004)

SC Resolution 1556 (30 July 2004)

SC Resolution 1565 (1 October 2004)

SC Resolution 1590 (24 March 2005)

SC Resolution 1706 (31 August 2006)

SC Resolution 1739 (10 January 2007)

SC Resolution 1741 (30 January 2007)

SC Resolution 1750 (30 March 2007)

SC Resolution 1751 (13 April 2007)

SC Resolution 1754 (30 April 2007)

SC Resolution 1755 (30 April 2007)

SC Resolution 690 (29 April 1991)

SC Resolution 886 (22 September 1993)

Security and human rights for all UN Doc A/59/2005

UN Covenants on Civil and Political Rights and on Economic, Social and

Cultural Rights 1966

United Nations Security Council UN Doc A/50/60-S/1995/1 1995

United Nations Security Council UN Doc S/23500 1992

World Summit Outcome UN Doc A/RES/60/1 2005

World Summit Outcome UN Doc A/RES/60/180 2005

\section{List of abbreviations}

DRC Democratic Republic of the Congo

ECOWAS Economic Community of West African States

ia inter alia

ICJ International Court of Justice

IMF International Monetary Fund

$\mathrm{MINUCl} \quad$ United Nations Mission in Côte d'Ivoire

MINURSO Mission for the Referendum in Western Sahara 
MONUC United Nations Organisation Mission in the Democratic Republic of the Congo

OAU Organisation of African Unity

par paragraph(s)

POLISARIO Popular para la Liberación de Saguia el-Hamra y de Río de Oro

SPLM/A Sudan People's Liberation Movement/Army

UNAMIS United Nations Advance Mission in the Sudan

UNEF1 United Nations Emergency Force

UNESCAP United Nations Economic and Social Commission for Asia and the Pacific

UNMEE $\quad$ United Nations Mission in Ethiopia and Eritrea

UNMIL United Nations Mission in Liberia

UNMIS United Nations Mission in the Sudan

UNOCl United Nations Operation in Côte d'Ivoire

UNOL United Nations Peace-building Support Office in Liberia

UNOMIL United Nations Observer Mission in Liberia

UNPROFOR United Nations Peacekeeping operation in Bosnia 